\title{
Cassava Bioindustrial Perspective
}

\author{
Pandi Pardian ${ }^{1}$, Tomy Perdana ${ }^{1}$, Trisna Insan Noor ${ }^{1}$ \\ ${ }^{1}$ Program Studi Agribisnis Jurusan Sosial Ekonomi Pertanian Universitas Padjadjaran
}

\begin{abstract}
Cassava is one of the commodities of food crops that mainly processed in food products. In addition to being the raw material, cassava food products also have the potential as raw materials for making bioplastics. Processing cassava into bioplastics is carried out by bio-industrial, so the discussion about the process of utilizing cassava up to being bioplastic is interesting to explore. The results of descriptive analysis and literature sharing show that the cassava bio-industry is more environmentally friendly because the production in the form of bioplastic is easier to decompose compared to fossil plastics, the production process with the concept of circulation has the ability to eliminate waste
\end{abstract}

\section{Introduction}

The agricultural sector is vital in providing food needs, so the role of the agricultural sector is increasingly important in development activities. The agricultural sector is not only a producer of foodstuffs but also to meet the needs for feed and fiber as well as a source of energy (fuel) due to the decreasing number of energy sources that come from non-renewable (fossil) sources such as petroleum, gas, and others. Also, public awareness of the environment is increasing due to many negative impacts from the process of utilizing natural resources that do not pay attention to environmental conditions. Realizing that, agricultural development involving technology has changed to a biological revolution (bio revolution).

Therefore, agricultural activity has led to the concept of sustainability to minimize or eliminate negative influences on the environment and human health. Sustainability in agriculture is performed in applying the bio-industrial concept to increase product value and environmentally friendly. Many definitions of bioindustry, one of that is an industry that implementing the system of biological process or change (transformation), including industries that apply biotechnology [1]. Bioindustry is also a part of biotechnology, that applicated of microorganisms and enzymes on large scale (industry) which takes into account economic studies and the advantages and disadvantages of the production process [2].

Bioindustry by utilizing agricultural commodities in Indonesia can be performed because it has a variety of food crops, horticulture, and plantations. The agricultural commodity that can use as raw material for bio-industry is cassava commodity, although it is a food plant, not the main foodstuffs because often just a complementary food and used more raw material for processed food and also not a strategic plant. Besides that, cassava plants are easy to maintain and can grow in all of the Indonesian regions.

Cassava is one of the foodstuffs containing carbohydrates other than rice. Therefore, cassava is a sought-after food source in Indonesia. However, in Indonesia, the selling price of cassava has a low level of around Rp.500-Rp.1800 per kilogram at the farmer level. So many processed so various other food products such as chips on the industrial scale, tapioca flour, and others.

he added value of cassava commodities resulting from the development of downstream industries (processed products) is much higher than the upstream industry (primary products), so agricultural commodities should be directed towards expanding the added value of products including their waste by bioindustry processing. The description above regarding the commodity of cassava, it is interesting to explanation about the scheme the perspective of the cassava bioindustry in this paper

\section{Methods}

This study employs a literature and exploration and discovery that contributes to developing an understanding. This research was conducted by collecting data/ information secondary on cassava for bioindustrial purposes

\section{Result}

BPS (Central statistical agency) data shows that cassava production and consumption data from 20142018 has decreased. Despite the decline, the level of production is still higher than consumption. In its development, the decline in production was greater than the decrease in consumption. Many things influenced it, one of which was the reduced role of cassava to meet the

\footnotetext{
*Corresponding author: pandi.pardian@unpad.ac.id
} 
food needs of the community. The consumption of cassava is often associated with household welfare, especially in rural areas. If a household is very poor, then sometimes it cannot afford to buy rice, so the staple food alternates between eating rice and eating cassava. However, if a household is well-off enough, eating cassava is only as a snack [5].

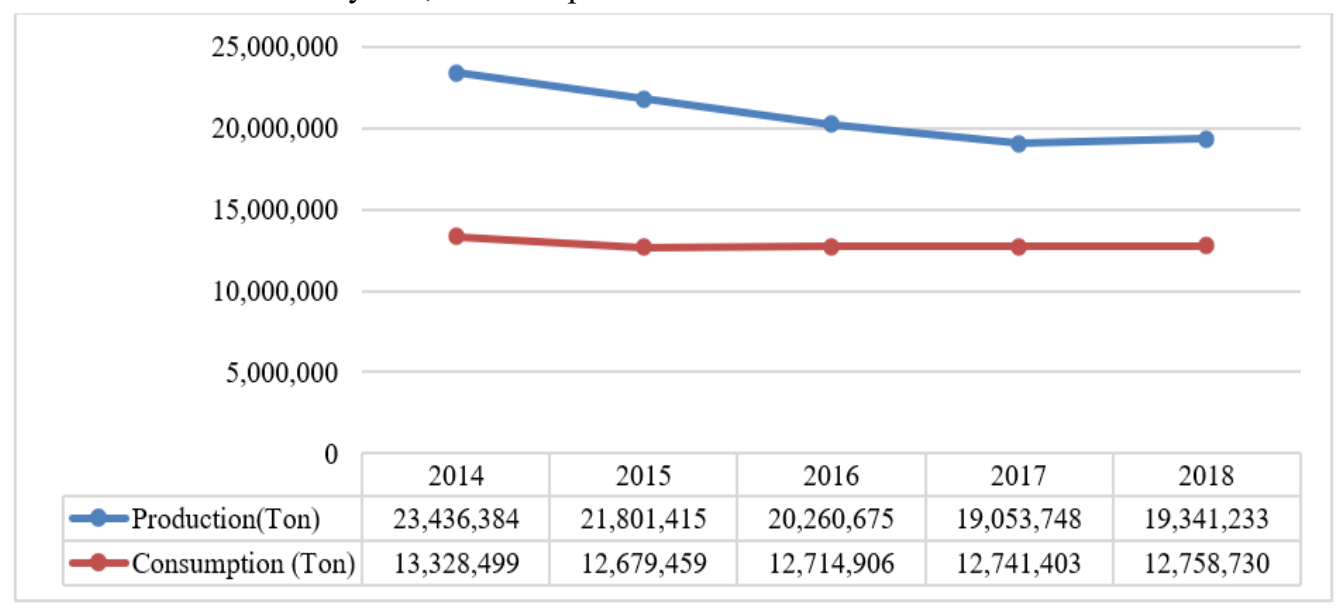

Fig 1. Indonesian Cassava Production and Consumption 2014-2018 (Ton)

Indonesian cassava production centers are located in 5 provinces, among which the largest cassava producer areas are Lampung Province, then Central Java, East Java, West Java, and DI Yogyakarta. The ability to produce cassava commodities in each region is not accompanied by the ability of the processing industry to increase the value of cassava and only acts as a production center and then distributed to companies that process cassava into cassava flour (tapioca). The large difference in the amount of production compared to consumption provides an opportunity to make cassava a raw material for bioindustry products that produce non-food products (bioplastics) so that they can provide more benefits to reduce plastic waste or become more valuable and environmentally.

Table 1. 5 Provinces with the Largest Cassava Production 2014-2017

\begin{tabular}{|c|c|c|c|c|c|c|}
\hline \multirow{2}{*}{ Province } & \multicolumn{4}{|c|}{ Years } & \multirow{2}{*}{$\begin{array}{c}\text { Percentage } \\
(\%)\end{array}$} & \multirow[t]{2}{*}{ Indonesia } \\
\hline & 2014 & 2015 & 2016 & 2017 & & \\
\hline Lampung & $8,034,016$ & $7,387,084$ & $6,481,382$ & $5,451,312$ & $28.61 \%$ & \multirow{5}{*}{$75.71 \%$} \\
\hline West Java & $2,250,024$ & $2,000,224$ & $1,792,716$ & $1,901,433$ & $9.98 \%$ & \\
\hline Central Java & $3,977,810$ & $3,571,594$ & $3,536,711$ & $3,138,864$ & $16.47 \%$ & \\
\hline DI Yogyakarta & 884,931 & 873,362 & $1,125,375$ & $1,025,693$ & $5.38 \%$ & \\
\hline East Java & $3,635,454$ & $3,161,573$ & $2,924,933$ & $2,908,417$ & $15.26 \%$ & \\
\hline
\end{tabular}

The five cassava producing provinces contribute more than $75 \%$ to national cassava production with Lampung Province as the largest producer of cassava commodity. Looking at the development of production and consumption, the opportunity to increase the value of cassava products and maximize production absorption, the cassava bio-industry is an alternative to be developed. The Bioindustry concept that implements a circular production process able to reduce and eliminate the waste impact from the production process.

Cassava's Agricultural-Bioindustrial Systems perspective is an effort to manage and produce products that are beneficial for improved well-being by reducing the impact on the environment and protecting natural resources. Bioindustrial products from cassava one of them is bioplastic very environmentally friendly

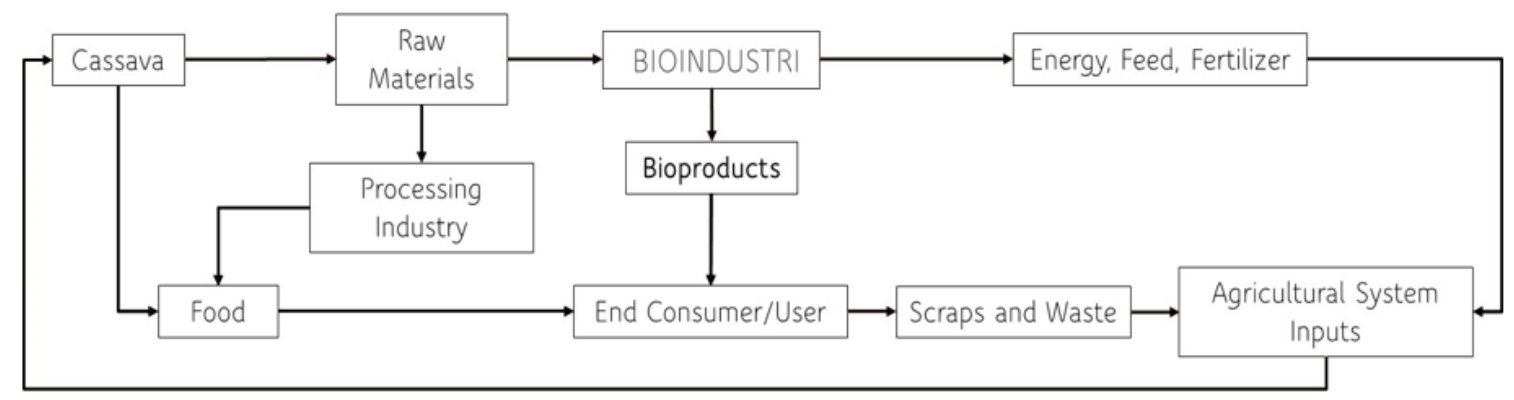

Fig.2. Cassava Bioindustry schema with circular process

The above scheme shown the scheme form of cassava bio-industrial processing friendly to the environment and produces useful products but not cause waste accumulation because it is difficult to decompose. 
The main product of bioindustry is a bioplastic that is easily and quickly decomposed, different from plastics whose raw materials from fossils take hundreds even thousands of years to decompose which causes the accumulation of waste every year.

Apart from the cassava tuber which taken starch as raw material for bioplastic because of its starches content in the amount of $32.4 \%$, cassava peels also contain carbohydrates that can be extracted as starch with the carbohydrate content is $4.55 \%$ [4]. if seeing from the strength and flexibility, the best ratio to make biodegradable plastic (bioplastic) is a composition of $100 \%$ cassava tuber starch and $0 \%$ cassava peel flour [4]. Although this composition is the best composition, in practice not performed by bioindustry that makes bioplastic because of the negative nature of plastic products from cassava peels which still carry cyanide compounds in bioplastic products [3]. So that more bioindustry prioritizes using cassava tuber as raw material to make bioplastic while the cassava peels processed into fertilizer.

\section{Conclusion}

Cassava processing bio-industrial is not limited to partial processing but includes the processing of all biomass from farmers. Cassava Bioindustrial Perspective is the integration of the agricultural products system and processing industry as a unit of biosystem engineering in circular process thus eliminating waste (garbage)

\section{References}

1. A. Hermawan dan F. Rudi Prasetyo, Peluang Pengembangan Bioindustri Pertanian

Berkelanjutan Di Tingkat Petani, 3-9

Pengembangan Bioindustri Di Tingkat Petani

Badan Penelitian dan Pengembangan Pertanian (2014)

2. Mangunwidjaja, D, Inovasi dan

Technopreneurship, National conference, IPB

International Convention Center, Bogor, 18-19 Februari (2013)

3. N. M. Sabrina, Bioindustri: Definisi dan Ruang Lingkup. Laboratorium Bioindustri, Jurusan Teknologi Industri Pertanian. Universitas Brawijaya, Malang (2012)

4. N. Asni, D. Saleh, N. Rahmawati, Plastik Biodegradable Berbahan Ampas Singkong Dan Polivinil Asetat, Proceeding Physics National Seminar Vol.IV October (2015)

5. M. H. Pulungan, N.Hidayat, A. Wafa, K. Wardina, Pendayagunaan Pati Singkong dan Tepung Kulit Singkong sebagai Bahan Pembuatan Plastik Biodegradable (Kajian Rasio Pati Singkong dan Tepung Kulit Singkong) in Proceedings of national seminar on Kulit, Karet dan Plastik ke-7, 29 Agustus (2018)

6. R. Elizabeth, I. S. Anugrah, Bioindustry Agriculture Improve Competitiveness Of Agroindustry Products And Sustainable
Agriculture Development, Journal On Mimbar Agribisnis Vol 6 no.2 Juli (2020)

7. Pusdatin, Outlook Komoditas Pertanian sub Sektor Tanaman Pangan Indonesia, Ministry of agriculture (2016) 